\title{
Induction of chalcone synthase and phenylalanine ammonia-lyase by salicylic acid and Colletotrichum lindemuthianum in common bean
}

\author{
Ângela Diniz Campos ${ }^{*}$, Alfredo Gui Ferreira², Magdolna Maria Vozári Hampe ${ }^{3}$, Irajá Ferreira Antunes ${ }^{1}$, \\ Nely Brancão ${ }^{1}$, Expedito P. Silveira ${ }^{1}$, João Batista da Silva ${ }^{4}$, Vera Algayer Osório ${ }^{1}$
}

${ }^{1}$ Laboratório de Fisiologia Vegetal, Embrapa Clima Temperado, CP 403, CEP 96001-970, Pelotas RS, Brasil; 2Instituto de Biociências UFRGS, Departamento de Botânica, Porto Alegre, RS, Brasil; ${ }^{3}$ Instituto de Ciências Básicas da Saúde - UFRGS, Departamento de Bioquímica, Porto Alegre, RS, Brasil; ${ }^{4}$ Instituto de Física e Matemática - UFPEL, Departamento de Física, matemática, e computação *Corresponding author: angela@cpact.embrapa.br

Received: 25/05/2002, Accepted: 30/08/2003

The activities of the enzymes chalcone synthase (CHS) and phenylalanine ammonia-lyase (PAL) were measured in leaf extracts obtained from four cultivars of the common bean (AB 136, Rio Tibagi, Carioca and Macanudo). Two stages of plant development were examined: plantlets (V2) and the onset of blooming (R6). Initially, the plants were either treated with salicylic acid or inoculated with the delta race of Colletotrichum lindemuthianum (inductive fungus) and after three days they were evaluated for enzyme activity. Afterwards, all plants were inoculated (challenged) with the virulent pathotype 33/95 of $C$. lindemuthianum except for the water control. Five days later, the activities of PAL and CHS were evaluated. There were significant changes in the activities of both enzymes three days after treatment with salicylic acid or inductive fungus when compared to the control. Five days after inoculation with with the virulent pathotype 33/95 of C. lindemuthianum CHS activity in the Macanudo was similar to control plants that were not treated with salicylic acid or the inductive fungus but inoculated with 33/95 C. lindemuthianum. The increase in enzyme activity after challenge with 33/95 C. lindemuthianum was greatest for the salicylic acid treatment in the cultivar AB 136, followed by Rio Tibagi and Carioca.

Key words: anthracnose, Phaseolus vulgaris, systemic acquired resistance.

Indução da chalcona sintase e da fenilalanina amônia-liase por ácido salicílico e Colletotrichum lindemuthianum em feijão: As atividades das enzimas chalcona sintase (CHS) e fenilalanina amônia-liase (PAL) foram avaliadas em extratos de folhas de quatro cultivares de feijão (AB 136, Rio Tibagi, Carioca e Macanudo), considerando-se dois estádios de desenvolvimento das plantas: plântulas (V2) e início de floração (R6). Inicialmente, as plantas foram tratadas com ácido salicílico ou inoculadas com a raça delta de Colletotrichum lindemuthianum (fungo indutor) e, após três dias, avaliadas quanto à atividade das enzimas. Em seguida, as plantas foram inoculadas com o patótipo virulento 33/95 de C. lindemuthianum, exceto as plantas-controle. Após cinco dias, avaliaram-se as atividades de PAL e CHS, observando-se acréscimos na atividade das enzimas, tanto no tratamento com ácido salić́lico quanto com o fungo indutor, quando comparados com o controle. Houve alterações significativas nas atividades das enzimas depois de três dias de exposição aos tratamentos indutivos com ácido salicílico e fungo, quando comparados com o controle não induzido. Cinco dias após a inoculação com o patótipo virulento 33/ 95 de C. lindemuthianum, a atividade de CHS em Macanudo foi semelhante às plantas-controles que não haviam sido induzidas, mas inoculadas com 33/95 C. lindemuthianum. O aumento das atividades depois do desafio com 33/95 C. lindemuthianum foi maior nas plantas tratadas com ácido salicílico no cultivar AB 136, seguido por Rio Tibagi e Carioca.

Palavras-chaves: antracnose, Phaseolus vulgaris, resistência sistêmica adquirida. 


\section{INTRODUCTION}

Plants can develop systemic, durable, and wide-spectrum resistance induced by pathogens or some chemical products, a phenomenon known as "Systemic Acquired Resistance" (SAR). The wide spectrum of action of SAR contrasts with the resistance against specific pathogen races provided by major resistance genes used in developed cultivars and, therefore, it can be less susceptible to resistance breakdown (Moraes, 1998). Induced resistance is recognized as an important biocontrol method in the production of organic vegetables (Sequeira, 1983).

The plant cell wall also participates in resistance mechanisms, since it plays a role in active defense that may result in an accumulation of phytoalexins, which are antibiotic substances of low molecular weight synthesized and accumulated in plants after exposure to microorganisms (Braga and Dietrich, 1987; Seki et al., 1999; Pelicice et al., 2000). Phytoalexins and the enzymes that catalyze their synthesis appear at low concentrations or are absent from healthy plants, but they can be synthesized when the plants are exposed to certain pathogens or other abiotic stresses (i.e. wounding, extreme temperatures, etc.) (Chet, 1993). The production of phytoalexins is increased by the action of some factors, such as exogenous elicitors that are produced by pathogens, or endogenous elicitors that are produced by the plants in response to stress situations (Zarra and Revilla, 1996; Seki et al., 1999). For example, one defense mechanism of legumes to mildew infection is the rapid accumulation of antimicrobial phytoalexins and isoflavonoids at the infected area (Dixon, 1986), including the production of phenylpropanoids (Dixon and Harrison, 1990).

Phenylalanine ammonia-lyase (PAL; EC 4.3.1.5) and chalcone synthase (CHS; EC 2.3.1.74) are two key enzymes that are involved in phenylpropanoid biosynthesis (Smith and Banks, 1986). The first reaction of this biosynthetic pathway is the deamination of phenylalanine to cinnamic acid by PAL. In the next reaction of the metabolic pathway, CHS condenses three malonyl-CoA molecules with cinnamoyl-CoA to produce chalcone. This condensation is the main branch in the pathway for the production of flavonoids (Ryder et al., 1984, 1987; Cramer et al., 1989; Hahlbrock and Scheel, 1989). PAL and CHS catalyze key reactions in the biosynthesis of phytoalexin isoflavonoids in legumes. This is the first stage in the biosynthesis of secondary phenylpropanoid products by L-phenylalanine and the first reaction branch in the main flavonoid and isoflavonoid production pathway (Ellis et al., 1989).
The salicylic acid concentrations needed for PAL and CHS activation and for achieving disease resistance are not toxic and they reach a peak before the onset of SAR (Chet, 1993). Studies with parsley cells in culture revealed that salicylic acid, one of the typical compounds involved in SAR expression, renders cells sensitive to the elicitor, in a process originally called conditioning (Kauss and Jeblick, 1995). This process involves cell activation mechanisms and promotes responses with small elicitor doses, while in non-treated cells there is only a weak reaction (Kauss et al., 1992). Nevertheless, it has been demonstrated that although salicylic acid is involved in resistance induction, this substance is not responsible for the original signal that sensitizes plant tissues that are distant from the initial site of treatment, allowing the plant to respond to the pathogenic attack in a systemic manner.

It has been recently discovered that the enzyme salicylate synthase is a potent tool for the manipulation of salicylic acid levels in plants. By fusing the two bacterial genes $p c h A$ and $p c h B$ from Pseudomonas aeruginosa, which encode isochorismate synthase and isochorismate pyruvate-lyase, respectively, a novel hybrid enzyme was produced. Increases in salicylate synthase activity expressed in Arabidopsis thaliana were observed, while the free and conjugated salicylic acid content was increased more than 20 -fold above the wild type level (Mauch et al., 2001).

The objective of this work was to determine the efficiency of the delta race of the fungus $C$. lindemuthianum in the induction of PAL and CHS activities and compare it to the effect of salicylic acid with regard to the highly virulent 33/95 C. lindemuthianum pathotype, native of Rio Grande do Sul, on four Phaseolus vulgaris L. cultivars.

\section{MATERIAL AND METHODS}

This study took place at the Embrapa Temperate Climate Experimental Station (Embrapa Clima Temperado) in the State of Rio Grande do Sul, Universidade Federal do Rio Grande do Sul (UFRGS). Two experiments were carried out at two developmental stages of the bean (Phaseolus vulgaris L.) cultivars AB 136, Carioca, Macanudo, and Rio Tibagi. The plants were maintained in the greenhouse at a temperature of $25 \pm 2{ }^{\circ} \mathrm{C}$ and relative humidity of $79 \pm 5 \%$, with a $14 \mathrm{~h}$ photoperiod and $195 \mu \mathrm{mol} \cdot \mathrm{s}^{-1} \cdot \mathrm{m}^{-2}$ illumination. The two fungal races were obtained from Embrapa's plant pathology program.

In the first experiment, the seeds were sown in plastic trays $(55 \times 40 \times 15 \mathrm{~cm})$ filled with sterilized sand and irrigated with nutrient solution (Smith et al., 1963). The germi- 
nated seeds were left to grow for nine days, reaching the plantlet stage at which the primary leaves become expanded (V2). In the second experiment, the seeds were germinated in plastic bags containing $3 \mathrm{Kg}$ of a sterilized soil mixture (soil, manure and vermiculite, 5:3:1, v/v/v). The plants grew until the onset of the blooming stage (R6). Spores $\left(1.4 \times 10^{6}\right.$ spores. $\mathrm{ml}^{-1}$ ) of the delta race of $C$. lindemuthianum (inductive fungus) or $10 \mathrm{mmol} . \mathrm{L}^{-1}$ salicylic acid were separately sprayed in all the leaves with a hand atomizer. After three days the plants were assessed, and challenged with the virulent isolate 33/95 of C. lindemuthianum (at a concentration of $2.27 \times 10^{4}$ spores $\mathrm{ml}^{-1}$ ) and reevaluated five days later. Mathur's medium was used to produce the inoculum (Mathur et al., 1950). Plants were sprayed with water in the control treatment. Once inoculated, the plants were kept at air temperature and relative humidity of $22 \pm 2{ }^{\circ} \mathrm{C}$ and $95 \%$, respectively. Photosynthetic photon flux density was approximately $195 \mu \mathrm{E} \mathrm{s}^{-1} \cdot \mathrm{m}^{-2}$ during $14 \mathrm{~h}$ per day.

Leaves were collected at random from the whole plants three days after the induction treatments, and five days after challenge with the virulent pathotype (Irving and Kuc, 1990). The tissue was weighed, rapidly frozen on dry ice, and stored at $-80{ }^{\circ} \mathrm{C}$ for later analysis.

The CHS extraction was carried out by grinding the leaves with $300 \mu \mathrm{l} 50 \mathrm{mmol} . \mathrm{L}^{-1} \mathrm{KH}_{2} \mathrm{PO}_{4}$, $\mathrm{pH} 8.0$, containing 20 mmol. $\mathrm{L}^{-1}$ ascorbic acid. The mixture was ultrasonicated in ice for $2 \mathrm{~min}$ and centrifuged $\left(25,000 \mathrm{~g}_{\mathrm{n}}, 15 \mathrm{~min}\right)$. The activity of CHS was determined according to Edwards and Kessman (1990) using $100 \mu 1$ of the supernatant.

PAL activity was determined in crude leaf extracts obtained by grinding the leaves with $4 \mathrm{ml}$ of $0.5 \mathrm{~mol}^{\mathrm{L}} \mathrm{L}^{-1}$ borate buffer $\left(4{ }^{\circ} \mathrm{C}\right)$ containing $0.05 \mathrm{~g}$ of polyvinylpyrrolidone in a Polytron mixer at full speed. The protein extract obtained after filtration (Whatman 1) and centrifugation $\left(25,000 g_{\mathrm{n}}, 15 \mathrm{~min}\right)$ was used to assay the PAL activity (Hyodo and Yang, 1971; Hyodo et al., 1978).

Protein concentration in the extracts was determined by the Lowry method (Lowry et al., 1951).

The experiments were designed according to a split plot arrangement in randomized complete design with factors A (cultivars) x B (treatments) and 5 replicates. The sample analyses were done in triplicate and the enzyme specific activities were subjected to analysis of variance. The correlation coefficients were calculated according to Zonta and Machado (1984) and means were compared using the Duncan test $( \pm=0.05)$.

\section{RESULTS AND DISCUSSION}

Cultivars AB 136, Rio Tibagi and Carioca at stages V2 and R6 showed significant increase in PAL activity after treatment with salicylic acid or inoculation with the inductive fungus in relation to the control. No significant differences occurred between the treatments with salicylic acid and the inductive fungus for cultivar Macanudo after inoculation with the virulent pathotype at both developmental stages (tables 1 and 2).

After challenging with the virulent pathotype of $C$. lindemuthianum PAL activities in both growth stages continued to increase. Except for Macanudo, the other cultivars had higher activity than the control plants not induced with salicylic acid and the inductive fungus. These control plants however, also showed higher PAL activity than the absolute control plants, which were not induced or challenged.

Table 1. PAL activity of bean plantlets at the V2 stage of cultivars AB 136, Rio Tibagi, Carioca, and Macanudo three days after treatment with salicylic acid or inoculation with the delta race of $C$. lindemuthianum and five days after challenge with the virulent pathotype 33/95 of C. lindemuthianum .

PAL activity $\left(\text { nmol.h } \mathrm{h}^{-1} \cdot \mathrm{mg}^{-1} \text { protein }\right)^{\mathrm{a}}$

\begin{tabular}{|c|c|c|c|c|c|c|c|c|}
\hline \multirow[t]{2}{*}{ Treatments } & \multicolumn{4}{|c|}{ Three days after induction } & \multicolumn{4}{|c|}{ Five days after challenge } \\
\hline & AB 136 & Rio Tibagi & Carioca & Macanudo & AB 136 & Rio Tibagi & Carioca & Macanudo \\
\hline Salicylic acid & $60.43 \mathrm{a}$ & $49.70 \mathrm{a}$ & $36.07 \mathrm{a}$ & $51.13 \mathrm{a}$ & $97.60 \mathrm{a}$ & $77.27 \mathrm{a}$ & $40.37 \mathrm{a}$ & $79.73 a$ \\
\hline C. lindemuthianum (delta race) & $56.33 b$ & $47.63 b$ & $34.20 \mathrm{~b}$ & $50.07 \mathrm{a}$ & $89.00 \mathrm{~b}$ & $71.73 b$ & $38.10 \mathrm{~b}$ & $78.50 \mathrm{a}$ \\
\hline Control & $27.80 \mathrm{c}$ & $23.83 \mathrm{c}$ & $20.50 \mathrm{c}$ & $24.73 b$ & $34.30 \mathrm{~d}$ & $26.63 d$ & $22.63 d$ & $29.00 \mathrm{c}$ \\
\hline Virulent pathotype & & & & & $83.96 \mathrm{c}$ & $55.20 \mathrm{c}$ & $33.53 \mathrm{c}$ & $62.13 b$ \\
\hline
\end{tabular}

${ }^{a}$ Means followed by different letters in the same column are significantly different (Duncan test at $p \leq 0.05$ ). 
Table 2. PAL activity of bean plant at the R6 stage of cultivars AB 136, Rio Tibagi, Carioca and Macanudo three days after treatment with salicylic acid or inoculation with the delta race of $C$. lindemuthianum and five days after challenge with the virulent pathotype 33/95 of C. lindemuthianum.

PAL activity $\left(\text { nmol. } \mathrm{h}^{-1} \cdot \mathrm{mg}^{-1} \text { protein }\right)^{\mathrm{a}}$

\begin{tabular}{|c|c|c|c|c|c|c|c|c|}
\hline \multirow[t]{2}{*}{ Treatments } & \multicolumn{4}{|c|}{ Three days after induction } & \multicolumn{4}{|c|}{ Five days after challenge } \\
\hline & AB 136 & Rio Tibagi & Carioca & Macanudo & AB 136 & Rio Tibagi & Carioca & Macanudo \\
\hline Salicylic acid & $52.23 \mathrm{a}$ & $37.40 \mathrm{a}$ & $28.53 \mathrm{a}$ & $39.56 \mathrm{a}$ & $69.76 \mathrm{a}$ & $57.23 \mathrm{a}$ & $39.17 \mathrm{a}$ & $58.43 \mathrm{a}$ \\
\hline C. lindemuthianum (delta race) & $46.83 b$ & $35.56 \mathrm{~b}$ & $26.40 \mathrm{~b}$ & $38.73 a$ & $67.93 b$ & $54.10 \mathrm{~b}$ & $36.06 \mathrm{~b}$ & $57.80 \mathrm{a}$ \\
\hline Control & $25.60 \mathrm{c}$ & $19.00 \mathrm{c}$ & $13.73 \mathrm{c}$ & $20.30 \mathrm{~b}$ & $26.90 \mathrm{~d}$ & $20.80 \mathrm{~d}$ & $16.30 \mathrm{~d}$ & $20.36 \mathrm{c}$ \\
\hline Virulent pathotype & & & & & $64.40 \mathrm{c}$ & $47.73 \mathrm{c}$ & $25.46 \mathrm{c}$ & $54.47 \mathrm{~b}$ \\
\hline
\end{tabular}

${ }^{a}$ Means followed by different letters in the same column are significantly different (Duncan test at $p \leq 0.05$ ).

These results are in agreement with those obtained by Cui et al. (1996), who observed a rapid increase in the activities of PAL and CHS in sorghum plantlets after inoculation with Bipolaris maydis. Orczyk et al. (1996) also obtained a fast induction of PAL activity as a response to the attack of this pathogen in sorghum. The increase in PAL activity has frequently been mentioned as a defense reaction of plants to pathogen attack, showing significant increases after infection by pathogens or wounding (Chet, 1993, Seki et al., 1999, Cui et al., 2000; Logemann et al., 2000). Tepper et al. (1989) suggest that there are differences in the relative levels and timing of PAL and CHS mRNA which accumulate in a cultivar in response to different elicitors, and that any relationship between elicitor activity and specificity of plant-microbe interaction is highty complex. They also observed that the variability between induction patterns was demonstrated between cultivars. In the present case, it seems possible that an additive effect occurred in cultivar Macanudo, causing an increase in the induction activity values of the enzyme by the elicitor that originated from the fungus. A similar effect was observed by Lawton and Lamb (1987) and Dixon and Harrison (1990) in a suspension of cultured bean cells.

CHS activity in beans was induced by the treatments with salicylic acid and by inoculation with the inductive fungus at both developmental stages (tables 3 and 4). No significant differences were observed between the treatments for the Carioca and Rio Tibagi cultivars at both developmental stages. These results are consistent with those observed by Tepper et al. (1989) and Tepper and Anderson (1990), since the different responses of the cultivars to the induction of PAL and CHS activity might be related to the specificity between the cultivar and the elicitor, therefore determining the activation of defense mechanisms.

Table 3. CHS activity of bean plantlets at the V2 stage of cultivars AB 136, Rio Tibagi, Carioca and Macanudo three days after treatment with salicylic acid or inoculation with the delta race of $C$. lindemuthianum and five days after challenge with the virulent pathotype 33/95 of C. lindemuthianum.

CHS activity (pmol $\mathrm{g}^{-1}$ protein) ${ }^{\mathrm{a}}$

\begin{tabular}{|c|c|c|c|c|c|c|c|c|}
\hline \multirow[t]{2}{*}{ Treatments } & \multicolumn{4}{|c|}{ Three days after induction } & \multicolumn{4}{|c|}{ Five days after challenge } \\
\hline & AB 136 & Rio Tibagi & Carioca & Macanudo & AB 136 & Rio Tibagi & Carioca & Macanudo \\
\hline Salicylic acid & $9.0 \mathrm{a}$ & $5.2 \mathrm{a}$ & $4.8 \mathrm{a}$ & $6.9 \mathrm{a}$ & $9.3 \mathrm{a}$ & $5.3 \mathrm{a}$ & $4.7 \mathrm{a}$ & $6.3 \mathrm{a}$ \\
\hline C. lindemuthianum (delta race) & $7.8 \mathrm{~b}$ & $4.9 \mathrm{a}$ & $4.7 \mathrm{a}$ & $6.8 \mathrm{a}$ & $8.3 b$ & $4.9 \mathrm{a}$ & $4.6 \mathrm{a}$ & $6.1 \mathrm{a}$ \\
\hline Control & $1.4 \mathrm{c}$ & $1.0 \mathrm{~b}$ & $0.9 b$ & $2.3 b$ & $1.6 \mathrm{~d}$ & $0.9 \mathrm{c}$ & $1.0 \mathrm{c}$ & $1.1 \mathrm{~b}$ \\
\hline Virulent pathotype & & & & & $7.7 \mathrm{c}$ & $4.2 b$ & $3.3 \mathrm{~b}$ & $5.9 \mathrm{a}$ \\
\hline
\end{tabular}

${ }^{a}$ Means followed by different letters in the same column are significantly different (Duncan test at $p \leq 0.05$ ). 
Table 4. CHS activity of bean plant at the R6 stage of cultivars AB 136, Rio Tibagi, Carioca and Macanudo three days after treatment with salicylic acid or inoculation with the delta race of $C$. lindemuthianum and five days after challenge with the virulent pathotype (33/95) of C. lindemuthianum.

CHS activity (pmol g-1 protein) ${ }^{\mathrm{a}}$

\begin{tabular}{|c|c|c|c|c|c|c|c|c|}
\hline \multirow[t]{2}{*}{ Treatments } & \multicolumn{4}{|c|}{ Three days after induction } & \multicolumn{4}{|c|}{ Five days after challenge } \\
\hline & AB 136 & Rio Tibagi & Carioca & Macanudo & AB 136 & Rio Tibagi & Carioca & Macanudo \\
\hline Salicylic acid & $9.1 \mathrm{a}$ & $5.2 \mathrm{a}$ & $4.8 \mathrm{a}$ & $6.9 \mathrm{a}$ & $9.0 \mathrm{a}$ & $5.2 \mathrm{a}$ & $4.7 \mathrm{a}$ & $6.9 \mathrm{a}$ \\
\hline C. lindemuthianum (delta race) & $7.9 \mathrm{~b}$ & $4.9 \mathrm{a}$ & $4.8 \mathrm{a}$ & $6.1 b$ & $7.8 \mathrm{c}$ & $4.9 \mathrm{a}$ & $4.6 \mathrm{a}$ & $6.2 \mathrm{~b}$ \\
\hline Control & $1.4 \mathrm{c}$ & $1.0 \mathrm{~b}$ & $0.9 b$ & $2.3 b$ & $1.6 \mathrm{~d}$ & $1.0 \mathrm{c}$ & $1.0 \mathrm{c}$ & $1.1 \mathrm{c}$ \\
\hline Virulent pathotype & & & & & $8.4 \mathrm{~b}$ & $4.3 b$ & $3.5 \mathrm{~b}$ & $5.9 b$ \\
\hline
\end{tabular}

a Means followed by different letters in the same column are significantly different (Duncan test at $p \leq 0.05$ ).

After challenging, induced plants did not show an increase of CHS (tables 3 and 4). However, except Macanudo, the other cultivars showed higher CHS activity than the control plants also inoculated with the virulent pathotype.

In our study, the defenses of the AB 136 cultivar were probably triggered faster than in the other cultivars, who observed that this cultivar was resistant to several races of $C$. lindemuthianum, as demonstrated by Alzate-Marin (1997). A similar fact was confirmed by Cui et al. (2000) while working with cotton, in which the authors found that the induction of genes for the synthesis of terpenoid compounds in plants inoculated with Verticillium dahliae occurred earlier in resistant than in susceptible cultivars. They also observed that among the genes that encode the phenylpropanoid defense metabolism, mRNA of phenylalanine ammonia-lyase was expressed and mRNA coding for chalcone synthase was transcribed. These enzymes are needed for flavonoid biosynthesis. Caffeic acid $O$-methyltransferase, a key enzyme in lignin synthesis, was present at very high levels in the inoculated plants when compared to the water-treated controls.

Lower CHS and PAL enzymatic activities were detected in the water control treatments. However, after induction with salicylic acid, the inductive fungus, or the virulent pathotype we observed significant increases in the activities of these enzymes. However, it is interesting to observe that cultivar Carioca, which is considered susceptible, had lower enzyme activity in all developmental stages.

According to our results, the induction of the activity of the enzymes PAL (cv. Macanudo) and CHS (cvs. Rio Tibagi and Carioca) by $C$. lindemuthianum was equivalent to the induction by salicylic acid.
A complex response that involves the production of phytoalexin isoflavonoids may play a role in the different responses of the cultivars to the treatments, with the induction of enzymes CHS and PAL at different levels (Tepper et al., 1989) and the accumulation of phytoalexins (Hartleb, et al., 1997). The amount of enzyme mRNA accumulation would directly affect the biosynthesis of phenols and, possibly, CHS and PAL are involved in the increase of these compounds during the infection process (Hartleb et al., 1997).

In agreement with Nicholson and Hammerschmidt (1992), an increase in the activity of PAL can be considered as a biochemical marker for resistance, given that this enzyme is key for the necessary synthesis of phenols associated with resistance. Nevertheless, even if this hypothesis is correct, a specific interaction between the cultivar and the pathogen may occur.

Acknowledgments: We thank Dr. Arthur G. Fett-Neto, Dr. Sonia M. C. Dietrich and Dr. Eliane Augustin, and Dr. Darcy Camelatto for their useful suggestions, and CNPq (Brazilian Research Council) for fellowships awarded to A. D. Campos and A. G. Ferreira. Part of the financial support used for the development of this research was provided by FAPERGS.

\section{REFERENCES}

Alzate-Marin AL, Baia GS, Paula-Junior TJ, Carvalho GA, Barros EG, Moreira MA (1997) A inheritance of anthracnose resistance in common bean differential cultivar $\mathrm{AB}$ 136. Plant Dis. 81:996-998.

Braga MR, Dietrich SMC (1987) Defesas químicas de plantas: fitoalexinas. Acta Bot. Bras. 1:3-16.

Chet I (1993) Biotechnology in plant disease control. WileyLiss, New York. 
Cramer CL Edwards K, Dron M, Liang X, Dildane SL, Bolwel GP, Dixon RA, Lamb CJ, Schuch W (1989) Phenylalanine ammonia-lyase gene organization and structure. Plant Mol. Biol. 12:367-383.

Cui Y, Magili J, Frederiksen R, Magili C (1996) Chalcone synthase and phenylalanine ammonia-lyase mRNA levels following exposure of sorghum seedlings to three fungal pathogens. Physiol. Mol. Plant Pathol. 49:187-199.

Cui Y, Bell AA, Joost O, Magill C (2000) Expression of potential defense response genes in cotton. Physiol. Mol. Plant Pathol. 56:25-31.

Dixon RA (1986) The phytoalexin response: elicitation, signaling and the control of host gene expression. Bot. Rev. 61:239-291.

Dixon RA, Harrison MJ (1990) Activation, structure and organization of genes involved in microbial defense in plants. Adv. Gen. 28:165-234.

Edwards R, Kessmann H In: Bowles D J (1990) Molecular plant pathology: A practical approach. Oxford: IRL Press.

Ellis JS, Jennings AC, Edwards LA, Mavandad M, Lamb CJ, Dixon R (1989) Defense gene expression in elicitor-treated cell suspension cultures of French bean cv Imuna. Plant Cell Rep. 8:504-507.

Hahlbrock K, Scheel D (1989) Physiology and molecular biology of phenylpropanoid metabolism. Ann. Rev. Plant Physiol. 40:347-369.

Hartleb H, Heitefuss R, Hoppe H (1997) Resistance of crop plants against fungi. Fischer, Stuttgart. 544p.

Hyodo H, Kuroda H, Yang SH (1978) Introduction of PAL and increase in phenolics in lettuce in relation the development. Plant Physiol. 62:31-35.

Hyodo H, Yang SF (1971) Ethylene enhanced synthesis of phenylalanine ammonia-lyase in pea seedlings. Plant Physiol. 47:765-770.

Irving HR, Kuc J (1990) Local and systemic induction of peroxidase, chitinase and resistance in curcumber plants by $\mathrm{K}_{2} \mathrm{HPO}_{4}$. Physiol. Mol. Plant Pathol. 37:355-366.

Kauss H, Jeblick W (1995) Pretreatment of parsley suspension cells increases with salicylic acid enhances spontaneous and elicited production of $\mathrm{H}_{2} \mathrm{O}_{2}$. Plant Physiol. 108:1171-1178.

Kauss H, Theisinger-Hinkel E, Mindermann R, Conrath U (1992) Dichloroinsonicotinic and salicylic acid, inducers of systemic acquired resistance, enhance fungal elicitor responses in parsley cells. Cell Mol. Biol. 2:655-660.

Lawton MA, Lamb CJ (1987) Transcriptional activation of plant defense genes by fungal elicitor, wounding and infection. Mol. Cell Biol. 7:335-341.

Lowry OH, Rosebrough NR, Farr AL (1951) Protein measurement with the Folin-phenol reagent. J. Biol. Chem. 193:265-269.

Logemann E, Tavernaro A, Shulz W, Somssish IE, Hahlbrock K (2000) UV light selectively co induces supply pathways from primary metabolism and flavonoid secondary product formation in parsley. Proc. Natl. Acad. Sci. USA 97:1903-1907.
Mauch F, Mauch-Mani B, Gaille C, Kull B, Haas D, Reimann C (2001) Manipulation of salicylate content in Arabidopsis thaliana by the expression of an engineered bacterial salicylate synthase. Plant J. 25:67-77.

Mathur RS, Barnett HL, Lilly, UL (1950) Sporulation of Colletotricum lindemuthianum in culture. Phytopathology 40:104-114.

Moraes, MG (1998) Mecanismos da resistência sistêmica adquirida em plantas. In: Luz WC, Fernandes JM, Prestes AM, Picinini EC Revisão Anual de Patologia de Plantas. Passo Fundo, Embrapa Trigo 6:261-284.

Niccholson RL, Hammerschmidt R (1992) Phenolic compounds and their role disease resistance. Ann. Rev. Phytopathol. 30:369-389.

Orczyk W, Hipskind J, Neergaard E DE, Goldsbrough P (1996) Stimulation of phenylalanine ammonia-lyase in sorghum in response to inoculation with Bipolaris maydis. Physiol. Mol. Plant Pathol. 48:55-64.

Pelicice FM, Dietrich SMC, Braga MR (2000) Phytoalexin response of fifteen Brazilian soybean cultivars. Rev. Bras. Fisiol. Veg. 12:45-53.

Ryder TB, Cramer CL, Bell JN, Robbins MP, Dixon R.A, Lamb CJ (1984) Elicitor rapidly induces chalcone synthase mRNA in Phaseolus vulgaris cells at the onset of the phytoalexin defense response. Proc. Natl. Acad. Sci. USA 81:5724-5728.

Ryder TB, Hedrick SA, Bell JN, Liang X, Clouse SD, Lamb CJ (1987) Organization and differential activation of gene family encoding the plant defense enzyme chalcone synthase in Phaseolus vulgaris. Mol. Gen. Genet. 210:219-233.

Seki H, Nagasugi Y, Shiraishi T, Yamada T (1999) Changes in vivo DNA-protein interactions in pea phenylalanine ammonia-lyase and chalcone synthase gene promoter induced by fungal signal molecules. Plant Cell Physiol. 40:88-95.

Sequeira L (1983) Mechanisms of induced resistance in plants. Ann. Rev. Microbiol. 37:51-79.

Smith CA, Bailey CH, Hough LF (1963) Methods for germinating seeds of some fruit species with special reference to growing seedlings from immature embryos. Bull. State University of New Jersey, New Brunswick, 823:29p.

Smith DA, Banks SW (1986) Biosynthesis, elicitation and biological activity of isoflavonoid phytoalexins. Phytochemistry 25:979-995.

Tepper C, Albert FG, Anderson AJ (1989) Differential mRNA accumulation in three cultivars of bean in response to elicitors from Colletotrichum lindemuthianum. Physiol. Mol. Plant Pathol. 34:85-98.

Tepper C, Anderson AJ (1990) Interactions between pectic fragments and extra cellular components from the fungal pathogen Colletotrichum lindemuthianum. Physiol. Mol. Plant Pathol. 36:147-158.

Zarra I, Revilla G (1996) Pared celular. Estructura y función. In: Azcon-Bieto J, Talon M Fisiologia y bioquimica vegetal, pp. 1-24. Interamericana-McGraw-Hill, New York.

Zonta EP, Machado AA (1984) SANEST Sistema de análise estatística para microcomputadores. UFPEL, Pelotas . 